\title{
EFFICIENCY OF NITROGEN AND POTASSIUM APPLICATION ON PHYTOTECHNICAL PARAMETERS AND YIELD OF MELON
}

\author{
EFICIÊNCIA DA APLICAÇÃO DE NITROGÊNIO E POTÁSSIO SOBRE \\ CARACTERES FITOTÉCNICOS E RENDIMENTO DO MELOEIRO
}

\author{
Pablo Cristovão de Alencar FERNANDES ${ }^{1}$; Laércio da Silva PEREIRA ${ }^{2}$; \\ Carlos José Gonçalves de Souza LIMA ${ }^{3}$; Gabriel Barbosa da SILVA JÚNIOR ${ }^{4}$; \\ Theuldes Oldenrique da Silva SANTOS ${ }^{5}$; Regiana dos Santos MOURA ${ }^{6}$; \\ Everaldo Moreira da SILVA
}

1. Federal University of Piauí, Bom Jesus, PI, Brazil; 2. Postgraduate Program in Agronomy: irrigation and drainage, Paulista State University Júlio de Mesquita Filho, Botucatu, SP, Brazil; 3. Department of Agricultural Engineering and Soil Science, Federal University of Piauí, Teresina, PI, Brazil. carloslima@ufpi.edu.br; 4. Department of Plant Science, Federal University of Piauí, Teresina, PI, Brazil; 5. Technical College of Teresina, Federal University of Piauí, Teresina, PI, Brazil; 6. Postgraduate Program in Agricultural Engineering, Federal University of Recôncavo da Bahia, Cruz das Almas, BA, Brazil.

\begin{abstract}
Phytotechnical parameters, yield and fertilizer use efficiency are relevant to the rational management of fertigation, especially in cultivation of high technological level. Thus, the objective was to evaluate the influence and efficiency of nitrogen $(\mathrm{N})$ and potassium $(\mathrm{K})$ application on the phytotechnical parameters, yield and nutritional efficiency of yellow melon in a fertigation system. The experiment was conducted in the city of Bom Jesus-PI, Brazil, from January to April 2016, in a strip-block design with four replicates, and the treatments consisted of five $\mathrm{N}$ levels $\left(0,45,90,135\right.$ and $180 \mathrm{~kg} \mathrm{ha}^{-1}$ in the form of urea) and five $\mathrm{K}$ levels $\left(0,60,120,180\right.$ and $240 \mathrm{~kg} \mathrm{ha}^{-1}$ in the form of potassium chloride), applied through fertigation. Collar diameter, main branch length, leaf chlorophyll content, number of leaves, leaf area index, biomass accumulation, fruit yield, and $\mathrm{N}$ and $\mathrm{K}$ use efficiencies were evaluated. Applications of $180 \mathrm{~kg} \mathrm{ha}^{-1}$ of N and $240 \mathrm{~kg} \mathrm{ha}^{-1}$ of $\mathrm{K}$, respectively, led to the highest growth of the melon, while maximum production was obtained with the use of 112.50 and $165 \mathrm{~kg} \mathrm{ha}^{-1}$ of $\mathrm{N}$ and $\mathrm{K}$, respectively. The efficiency of $\mathrm{N}$ and $\mathrm{K}$ use decreased with increasing levels.
\end{abstract}

KEYWORDS: Cucumis melo. Fertigation. Fertilizer use efficiency.

\section{INTRODUCTION}

Melon (Cucumis melo L.), belonging to the Cucurbitaceae family, is a vegetable crop with high socioeconomic importance in Brazil, mainly for the Northeast region (HAGEL et al., 2019; IBGE, 2020). In 2018, this region was responsible for about $95.52 \%$ of the national production (IBGE, 2020), standing out for providing favorable climatic conditions for the development of the crop and because of the use of irrigation by the producers (HAGEL et al., 2019; IBGE, 2020).

Application of nitrogen and potassium fertilizers through fertigation can maximize growth and yield, in addition to increasing the efficiency of fertilizer use by the melon crop. Nitrogen $(\mathrm{N})$ is one of the most required nutrients by plants, actively acting on the synthesis of amino acids, proteins and chlorophyll, and favors their vegetative growth (ZÖRB; SENBAYRAM; PEITER, 2014; PERCHLIK; TEGEDERE, 2018).

Potassium (K) is one of the most abundant cations in plants, plays a key role in the transport of carbohydrates and in stomatal opening and closing, and is able to maximize the resistance of agricultural crops to disease attack, attenuate the effects of water stress, salt stress and toxicity caused by high concentrations of ammonium $\left(\mathrm{NH}_{4}^{+}\right)$in the soil (ZÖRB; SENBAYRAM; PEITER, 2014; Zahoor et al. (2017), in addition to improving the absorption and metabolism of N (DEBBARMA et al., 2017; ALI et al., 2019).

Despite the benefits promoted by $\mathrm{N}$ and $\mathrm{K}$ for plants, excessive applications of sources of these nutrients can cause leaching, reduce use efficiency, increase osmotic potential, reduce water absorption, compromise vegetative growth and biomass accumulation, significantly decrease crop yield, and increase production costs (OLIVEIRA et al., 2008). Hence, the application of nutrients should be optimized, considering the time and rate of absorption by crops

A study conducted by Colla, Suárez and Cardarelli (2010) points out that the maximum total yield, marketable yield, number of fruits and fruit weight for the melon crop were obtained with the 
use of $120 \mathrm{~kg} \mathrm{ha}^{-1}$ of $\mathrm{N}$ applied through fertigation. Castellanos et al. (2012) found maximum yield of Santa Claus melon with $\mathrm{N}$ application of $85 \mathrm{~kg} \mathrm{ha}^{-1}$ through fertigation. Evaluating melon yield under conventional fertilization with $\mathrm{N}$ and $\mathrm{K}$, Silva et al. (2014) found maximum yield with $\mathrm{N}$ and $\mathrm{K}$ applications of 320 and $640 \mathrm{~kg} \mathrm{ha}^{-1}$, respectively. However, Santos et al. (2018), under Cerrado conditions, found the highest yield of melon cultivars with conventional application of 90 and $200 \mathrm{~kg} \mathrm{ha}^{-1}$ of $\mathrm{N}$ and $\mathrm{K}$, respectively.

The quantities of $\mathrm{N}$ and $\mathrm{K}$ recommended for melon cultivation vary according to genotypic characteristics of cultivars, sources of fertilizers and their time of application, application technique (conventional or fertigation) and local edaphoclimatic conditions. Levels of $\mathrm{N}$ and $\mathrm{K}$ will promote greater growth and yield of the melon crop. Given the above, this study aimed to evaluate the efficiency of $\mathrm{N}$ and $\mathrm{K}$ levels applied through fertigation on the phytotechnical parameters, yield and nutritional efficiency of yellow melon in the southern region of Piauí state, Brazil.

\section{MATERIAL AND METHODS}

The experiment was conducted at São Luiz Farm, in the municipality of Bom Jesus-PI, Brazil, in an area of $2,500 \mathrm{~m}^{2}$, from January 29 to April 5, 2016. The location has the following geographic coordinates: latitude $-9^{\circ} 05^{\prime} 20.4^{\prime \prime} \mathrm{S}$, longitude - $44^{\circ}$ 20' 55.1" W and altitude of $283 \mathrm{~m}$. The climate of the region is dry sub-humid, according to Thornthwaite's classification, with average rainfall from 900 to $1200 \mathrm{~mm}$ year $^{-1}$ and average temperature of $26.5^{\circ} \mathrm{C}$ (MEDEIROS et al., 2016). The climatic conditions occurring during the experimental period are presented in Figure 1.
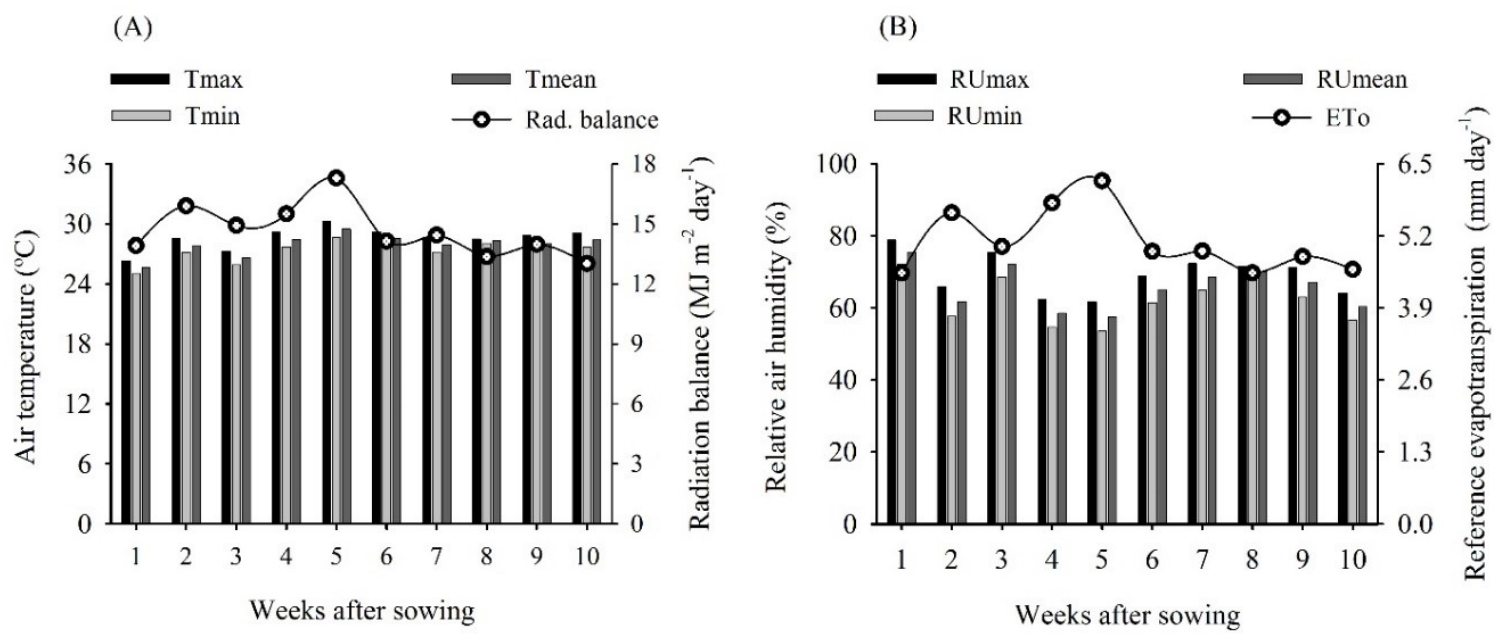

Figure 1. Weekly averages of maximum, mean and minimum air temperatures $\left({ }^{\circ} \mathrm{C}\right)$ and radiation balance $(\mathrm{MJ}$ $\mathrm{m}^{-2}$ day $^{-1}$ ) (A); maximum, mean and minimum relative air humidity (\%) and reference evapotranspiration $\left(\mathrm{mm} \mathrm{day}^{-1}\right)(\mathrm{B})$ observed during the experimental period. Bom Jesus-PI, 2015.

The soil of the experimental area is classified as Neossolo flúvico (Entisol) (EMBRAPA, 2018), with loamy sand and sand textural classes in the $0.0-0.20$ and $0.20-0.40 \mathrm{~m}$ layers, respectively. The soil was prepared by plowing/harrowing and liming was performed based on its chemical analysis, applying $1.05 \mathrm{Mg} \mathrm{ha}^{-1}$ of dolomitic limestone (93\% RNV).

At 30 days after correction, the soil had the following chemical and physical-hydraulic characteristics in the $0.0-0.20$ and $0.20-0.40 \mathrm{~m}$ layers, respectively: $\mathrm{pH}=5.3$ and 5.0; $\mathrm{P}=4.3$ and $2.4 \mathrm{mg} \mathrm{dm}^{-3} ; \mathrm{K}^{+}=53.0$ and $30.0 \mathrm{mg} \mathrm{dm}{ }^{-3} ; \mathrm{Ca}^{2+}=$ 2.1 and $1.5 \mathrm{cmol}_{\mathrm{c}} \mathrm{dm}^{-3} ; \mathrm{Mg}^{2+}=1.2$ and $0.9 \mathrm{cmol}_{\mathrm{c}}$ $\mathrm{dm}^{-3} ; \mathrm{S}=3.4$ and $4.0 \mathrm{mg} \mathrm{dm}^{-3}$; Organic matter $=$ 11.0 and $7.0 \mathrm{~g} \mathrm{dm}^{-3}$; Sand $=895$ and $902 \mathrm{~g} \mathrm{~kg}^{-1}$; Silt
$=42$ and $31 \mathrm{~g} \mathrm{~kg}^{-1}$; Clay $=63$ and $67 \mathrm{~g} \mathrm{~kg}^{-1}$; Particle density $=2.86$ and $2.70 \mathrm{~g} \mathrm{~cm}^{-3}$; Bulk density $=1.61$ and $1.64 \mathrm{~g} \mathrm{~cm}^{-3}$; Moisture content at field capacity $=$ 16.9 and $13.2(\%$, in volume) and Moisture content at permanent wilting point $=4.0$ and $4.5(\%$, in volume). Chemical and physical analyzes were carried out according to the methodology Embrapa (2017).

The experimental design was a strip-block design, with four replicates, and the treatments corresponded to the application of five $\mathrm{N}$ levels ( 0 , $45,90,135$ and $180 \mathrm{~kg} \mathrm{ha}^{-1}$ in the form of urea) and five $\mathrm{K}$ levels $\left(0,60,120,180\right.$ and $240 \mathrm{~kg} \mathrm{ha}^{-1}$ in the form of potassium chloride) applied through fertigation in the yellow melon crop. The experimental plots consisted of ten plants, totaling 
an area of $20 \mathrm{~m}^{2}$, and only the eight central plants were considered as usable plot.

Yellow melon, Diplomata F1 hybrid, was chosen because of its acceptance in the market and lack of technical information in the region. Its seeds were directly planted in the field, in holes with width, length and depth of $0.3,0.3$ and $0.3 \mathrm{~m}$, respectively, two seeds per hole, at spacing of 2.00 $\mathrm{m}$ between rows and $1.00 \mathrm{~m}$ between plants. Thinning was performed 15 days after sowing, maintaining one seedling per hole, based on the criteria of size and vigor.

The applications of $\mathrm{N}$ and $\mathrm{K}$ levels through fertigation were established according to the application rates of these nutrients for the melon crop (ANDRADE JÚNIOR; DIAS; FIGUEREDO JUNIOR, 2007). Phosphate fertilization was defined based on soil chemical analysis, according to the fertilizer recommendations for the Ceará state (AQUINO et al., 1993), applying $120 \mathrm{~kg} \mathrm{ha}^{-1}$ of single superphosphate in the holes, 20 days before sowing.

The crop was irrigated using a drip irrigation system, which consisted of a 3-hp pump with flow rate of $8.5 \mathrm{~m}^{3} \mathrm{~h}^{-1}$; 128-mesh disc filter; main and submain lines made of PVC pipe with nominal diameter (ND) of $50 \mathrm{~mm}$. Lateral lines were made of polyethylene with ND of $16 \mathrm{~mm}$ and length of $52 \mathrm{~m}$, with pressure-compensating online IDROP drippers, spaced by $1 \mathrm{~m}$, with unit flow rate of $8 \mathrm{~L} \mathrm{~h}^{-1}$ for an operating pressure of $10 \mathrm{mwc}$. Fertilizer solutions were injected in the system through a Venturi-type injector, with application rate of $80 \mathrm{~L} \mathrm{~h}^{-1}$ at operating pressure of $10 \mathrm{mwc}$.

The water used for irrigation came from a $150 \mathrm{~m}$ deep tubular well and was stored in a tank with width, length and depth of 3.0, 6.0 and $2.0 \mathrm{~m}$, respectively, and total capacity for $36 \mathrm{~m}^{3}$. The water had the following physicochemical characteristics: $\mathrm{EC}=30.22 \mu \mathrm{S} \mathrm{cm}^{-1} ; \mathrm{pH}=5.1 ; \mathrm{Ca}=1.0, \mathrm{Mg}=0.6$; $\mathrm{K}=0.4 ; \mathrm{Na}=3.9 ; \mathrm{Cl}=4.5 ; \mathrm{HCO}_{3}=3.4\left(\right.$ in $\mathrm{mg} \mathrm{L}^{-1}$ ), and was classified as of excellent quality for irrigation $\left(\mathrm{C}_{1} \mathrm{~S}_{1}\right)$ (HOLANDA et al., 2016).

Daily irrigation management was performed through the climatic method, based on the reference evapotranspiration (ETo) obtained by the PenmanMonteith method, adapted by FAO (ALLEN et al., 2006). Climatic data (Figure 1) were obtained by an automatic weather station, belonging to the National Institute of Meteorology (INMET), installed at the Federal University of Piauí (UFPI) in the city of Bom Jesus, on 'Prof'. Cinobelina Elvas' Campus CPCE, located at a distance of $1000 \mathrm{~m}$ from the experimental area, equipped with sensors of air temperature, relative air humidity, solar radiation and wind velocity, which were used to calculate the daily ETo.

Since wind velocity is obtained only at $10 \mathrm{~m}$ height in the weather stations belonging to INMET, the value was converted to $2 \mathrm{~m}$ height using the expression proposed by Allen et al. (2006). The crop coefficients (Kc) used were those proposed by the FAO methodology (ALLEN et al., 2006), adopting a basal $\mathrm{Kc}$ of 0.15 for the initial phase, 0.85 for the intermediate phase and 0.70 for the final phase. Kc values were adjusted for the local conditions of wind, minimum daily relative humidity and plant height, according to Allen et al. (2006).

Foliar applications of calcium $(6.0 \%-79.8$ $\left.\mathrm{g} \mathrm{L}^{-1}\right)$, magnesium $\left(2.0 \%-26.60 \mathrm{~g} \mathrm{~L}^{-1}\right)$ and boron $\left(1.0 \%\right.$ - $\left.13.33 \mathrm{~g} \mathrm{~L}^{-1}\right)$ were made using the product Liqui-Plex at 7-day intervals, from 33 to 55 days after sowing, which corresponded to the beginning of flowering and beginning of fruiting, respectively. Weeds were controlled by weeding every week and a preventive management was conducted for pests and diseases, with applications of products recommended for melon production.

Fruit harvest began at 65 days and ended at 68 days after emergence, and the harvest point was identified based on the cycle of the cultivar $(65$ days) and on the color change in the fruits, mainly in the region in direct contact with the soil, turning from yellow to light yellow.

Collar diameter was determined with a digital caliper (0.01-300 mm, Digimess $\AA)$, with measurements taken just below the cotyledonary leaves at the end of crop cycle. Branch length was measured from the cotyledonary leaves to the apical tuft, using a measuring tape. Leaf chlorophyll index was determined at three points on the 5th leaf (apex, center and base) with a chlorophyll meter (Falker®, Brazil).

The number of leaves per plant was obtained by counting all leaves of the plants in the usable plot. Leaf area index was estimated as the ratio between the existing leaf area and the surface occupied by the plant. Leaf and shoot dry biomasses were obtained in three plants of each plot by drying in forced circulation oven at temperature of $65^{\circ} \mathrm{C}$, until constant weight.

The following yield components were evaluated: average number of fruits per plant (fruit/plant), obtained by the individual count of the fruits from the usable area, divided by the number of plants in the plot; average fruit weight $(\mathrm{kg} /$ fruit), determined by the individual weighing of the fruits, divided by the total number of fruits harvested; and production per plant $\left(\mathrm{kg}\right.$ plant $\left.^{-1}\right)$, obtained by the 
relationship between the total weight of fruits in the plot divided by the number of plants in each plot.

Nitrogen use efficiency (NUE) and potassium use efficiency (KUE) $\left(\mathrm{kg} \mathrm{kg}^{-1}\right)$ were calculated by the expression: NUE $=$ (YWF$\mathrm{YNF} / \mathrm{Qa}$, where, YWF: crop yield with fertilizer $\left(\mathrm{kg} \mathrm{ha}^{-1}\right)$; YNF: crop yield with no fertilizer $\left(\mathrm{kg} \mathrm{ha}^{-}\right.$ $\left.{ }^{1}\right)$; Qa: quantity of nutrient applied $\left(\mathrm{kg} \mathrm{ha}{ }^{-1}\right)$ (PRADO, 2008).

The results were subjected to analysis of variance $(p<0,05)$. In case of significant single effect of the factors, quantitative analyses of polynomial regression were carried out. For the variables significantly affected by the interaction, response surface analyses were performed. The models used were selected based on the significance of the regression coefficients and on the highest value of coefficient of determination $\left(\mathrm{R}^{2}\right)$.

(A)

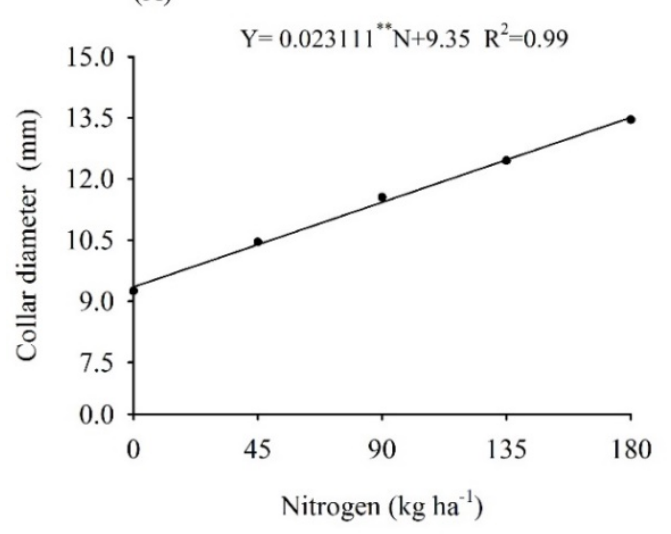

\section{RESULTS AND DISCUSSION}

The collar diameter (CD) and main branch length (MBL) of melon were influenced only by the $\mathrm{N}$ levels applied $(\mathrm{p}<0.01)$. The result of these variables fitted to an increasing linear regression model, with maximum of $13.45 \mathrm{~mm}$ and $1.50 \mathrm{~m}$, respectively, observed with $\mathrm{N}$ application of $180 \mathrm{~kg}$ $\mathrm{ha}^{-1}$ (Figure 1A and 1B). There were considerable gains of 31.22 and $38.29 \%$ in $\mathrm{CD}$ and $\mathrm{MBL}$, respectively, compared to the treatment under no $\mathrm{N}$ fertigation.

The increase observed in the vegetative growth of melon as the $\mathrm{N}$ levels increased in fertigation is justified by the contribution of this element to plant growth, acting on several physiological processes, such as growth, cell differentiation and division, and synthesis of amino acids and proteins. Its deficiency results in lower growth (PEREIRA FILHO et al., 2014; PERCHLIK; TEGEDERE, 2018).

(B)

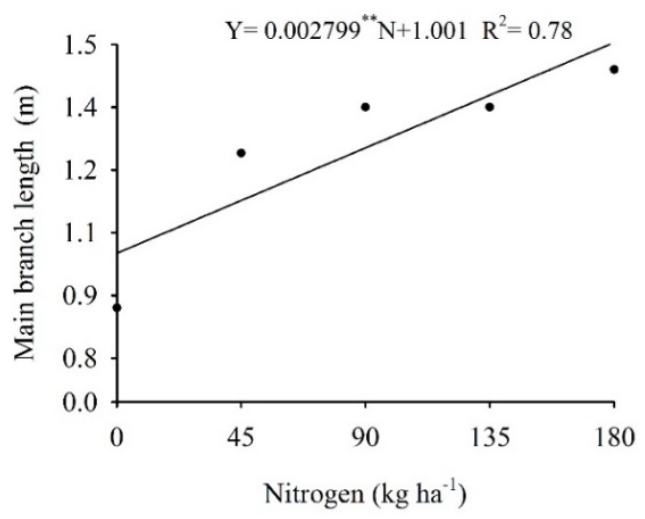

(C)

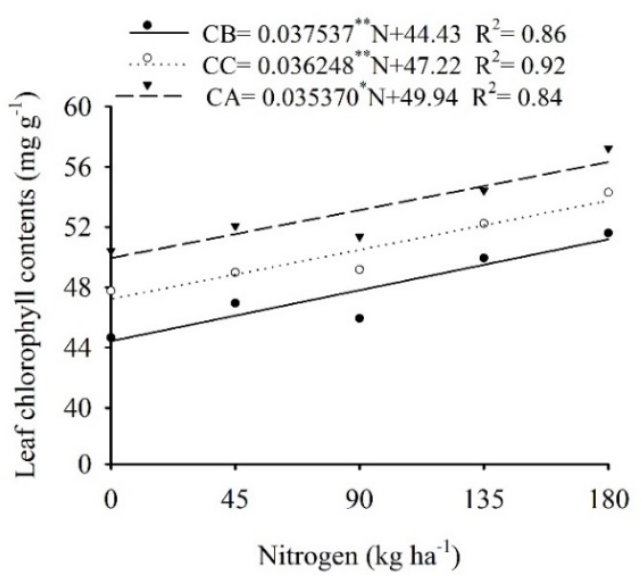

Figure 2. Regression for collar diameter (A), main branch length (B) and leaf chlorophyll contents at the base $(\mathrm{CB})$, center (CC) and apex (CA) (C) in melon plants as a function of nitrogen levels applied through fertigation.

** significant at $1 \%$ probability level, * significant at 5\% probability level by Student's t-test. 
Main branch elongation in melon plants leads to an increase in the number of primary and secondary branches, as well as in gain of leaf area due to the increase in the number and size of leaves, which can maximize the production of photoassimilates. In cantaloupe melon, Pereira Filho et al. (2014) found maximum CD and MBL of 13.05 $\mathrm{mm}$ and $1.70 \mathrm{~m}$, respectively, with the use of $90 \mathrm{~kg}$ $\mathrm{ha}^{-1}$ of $\mathrm{N}$, split and applied at $0,20,30$ and 50 days after sowing. It is possible to infer that these differences are related to the cultivars, irrigation management, method and time of fertilizer application and local edaphoclimatic conditions.

Leaf chlorophyll indices at the base (CB), center (CC) and apex (CA) were influenced by the $\mathrm{N}$ levels applied through fertigation $(\mathrm{p}<0.01)$. Leaf chlorophyll index is a physiological parameter related to the efficiency of $\mathrm{N}$ assimilation by plants, and low chlorophyll indices indicate low photosynthetic and physiological activity (ALI et al., 2019).

There was a significant increase in the indices $\mathrm{CB}, \mathrm{CC}$ and $\mathrm{CA}\left(51,18 ; 53,74 \mathrm{e} 56,30 \mathrm{mg} \mathrm{g}^{-}\right.$ ${ }^{1}$ ), respectively, as the $\mathrm{N}$ levels increased (Figure 1C). Despite the lower contents of leaf chlorophyll observed in the treatment without $\mathrm{N}$ application, melon plants grown under these conditions did not exhibit symptoms of nutritional deficiency, such as leaf yellowing and fall, and completed their entire cycle normally.

It is likely that, after soil correction with limestone, the mineralization of soil organic matter (plant residues) and nutrient availability contributed to the supply of $\mathrm{N}$ to the melon plants in the control treatment. This justifies the good numerical indices of the leaf chlorophyll contents found. Nitrogen fertilization linearly increased leaf chlorophyll content, due to the high capacity of this nutrient in promoting the synthesis of the chlorophyll molecule.

The number of leaves (NL), leaf area index (LAI), leaf dry mass (LDM) and shoot dry mass (SDM) were influenced by the significant interaction between factors $(p<0.01)$. The maximum expressions of NL, LAI, LDM and SDM of 199, $0.42,51.07$ and $64.42 \mathrm{~g} \mathrm{plant}^{-1}$, respectively, were obtained with the combination of $180 \mathrm{~kg} \mathrm{ha}^{-1}$ of $\mathrm{N}$ and $240 \mathrm{~kg} \mathrm{ha}^{-1}$ of $\mathrm{K}$ (Figure 3). It can be noted that, for these variables, $\mathrm{N}$ was the most limiting factor, which is confirmed by its greater slope in the response surfaces.
(A)

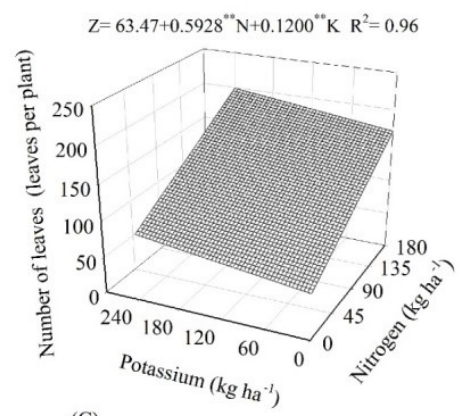

(C)

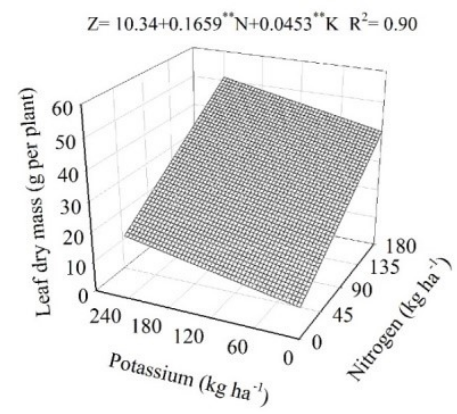

(B)

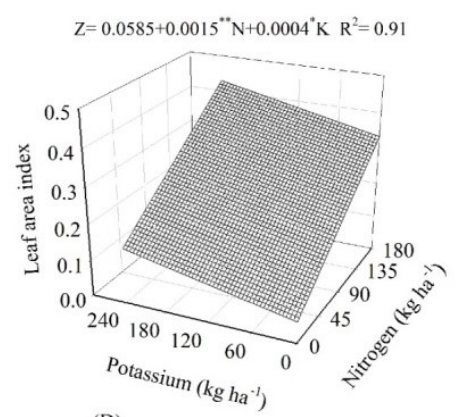

(D)

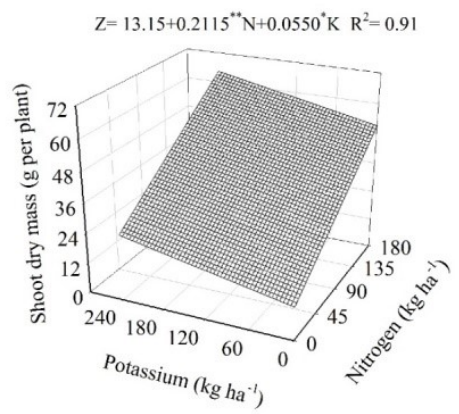

Figure 3. Response surfaces for the number of leaves (A), leaf area index (B), leaf dry mass (C) and shoot dry mass (D) of melon as a function of nitrogen and potassium levels applied through fertigation.

** significant at $1 \%$ probability level, * significant at $5 \%$ probability level by Student's t-test.

In the present study, the smallest expressions of growth and dry biomass accumulation were observed in melon plants that received $\mathrm{N}$ levels of 0 and $45 \mathrm{~kg} \mathrm{ha}^{-1}$ combined with $\mathrm{K}$ levels of 0 and $60 \mathrm{~kg} \mathrm{ha}^{-1}$, respectively. These results are attributed to the lower growth observed 
in these treatments, which resulted in a reduction in the size and number of leaves, consequently reducing leaf area index and dry biomass accumulation. Colla, Suárez and Cardarelli (2010) and Nascimento, Nascimento and Cecílio Filho (2020) also found reduction of leaf area and dry biomass accumulation in melon plants under conditions of low $\mathrm{N}$ availability.
The number of fruits (NFr) was only influenced by the $\mathrm{N}$ levels $(\mathrm{p}<0.05)$, and its data fitted to a quadratic regression model, with an estimated maximum of 2.9 fruits obtained with $\mathrm{N}$ application of $109.48 \mathrm{~kg} \mathrm{ha}^{-1}$ (Figure 4). There was a $66 \%$ increase in NFr compared to the treatment without application and a $30.34 \%$ reduction compared to the $\mathrm{N}$ application of $180 \mathrm{~kg} \mathrm{ha}^{-1}$.

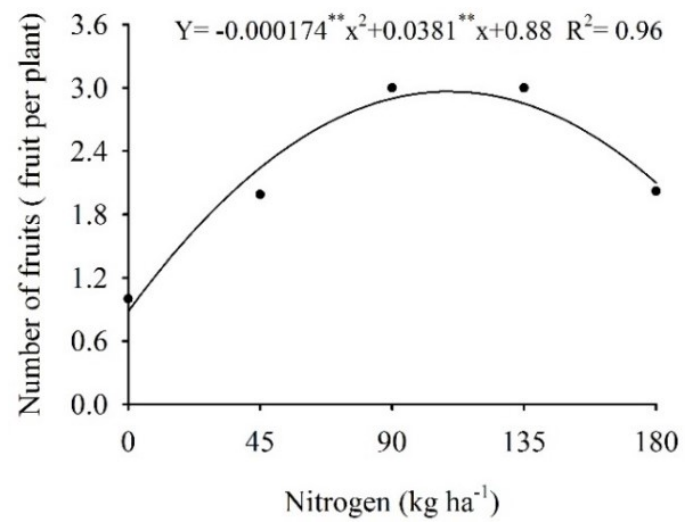

Figure 4. Regression for the number of fruits (fruit plant ${ }^{-1}$ ) of melon as a function of nitrogen levels.

** significant at $1 \%$ probability level by Student's t-test.

In aerated and not excessively acidic soils, such as the Neossolo (Entisol) of this study, $\mathrm{NH}_{4}{ }^{+}$is rapidly converted to nitrate (ZÖRB; SENBAYRAM; PEITER, 2014) and can be easily leached to layers not explored by the melon root system. This justifies the reduction of NFr at the highest level of $\mathrm{N}$ application through fertigation.

The average fruit weight (FW) of melon was influenced by the significant interaction between factors $(\mathrm{p}<0.05)$. It can be noted that $\mathrm{N}$ was the most limiting factor for this variable, which is evidenced by its greater curvature in the response surface (Figure 5A). When estimating the technically optimal levels for the production factors $\mathrm{N}$ and $\mathrm{K}$, it was found that the maximum $\mathrm{FW}$ of $1.35 \mathrm{~kg}$ /fruit was obtained under $\mathrm{N}$ and $\mathrm{K}$ applications of 101.25 and $165 \mathrm{~kg} \mathrm{ha}^{-1}$, respectively, with reduction in $\mathrm{FW}$ from these points.

The increments observed in vegetative growth and leaf chlorophyll synthesis at $\mathrm{N}$ and $\mathrm{K}$ levels of 180 and $240 \mathrm{~kg} \mathrm{ha}^{-1}$, respectively (Figures 2 and 3), did not lead to considerable gains in fruit weight, which can be justified by the lower translocation of photoassimilates to the fruits in these treatments. Reduction in FW with the increase in $\mathrm{N}$ level applied in the melon crop was also observed by Colla, Suárez and Cardarelli (2010). These authors found highest $\mathrm{FW}$ of $1.55 \mathrm{~kg}$ with $\mathrm{N}$ application of $60 \mathrm{~kg} \mathrm{ha}^{-1}$. Santos et al. (2018), under Cerrado conditions, also observed a decrease in the
FW of two melon varieties with $\mathrm{N}$ and $\mathrm{K}$ levels above 90 and $200 \mathrm{~kg} \mathrm{ha}^{-1}$, respectively.

$\mathrm{N}$ and $\mathrm{K}$ applications through fertigation influenced the production per plant (PP) (kg per plant) both as single factors and in interaction $(p<0.05)$. According to the equation represented in Figure 5B, the estimated maximum of $4.19 \mathrm{~kg}$ plant was obtained with 112.50 and $165 \mathrm{~kg} \mathrm{ha}^{-1}$ of $\mathrm{N}$ and $\mathrm{K}$, respectively.

It is possible to note a marked reduction in $\mathrm{PP}$ as the fertilizer levels increased. This behavior is related to the decrease in the mass and number of fruits at the highest rates of $\mathrm{N}$ and $\mathrm{K}$ application. The results observed in this study contradict those reported by Silva et al. (2014), who obtained linear increments in PP with $\mathrm{N}$ and $\mathrm{K}$ applications up to the levels of 320 and $640 \mathrm{~kg} \mathrm{ha}^{-1}$, respectively, in a Latossolo Vermelho distrófico (Oxisol).

A balanced fertilization with $\mathrm{N}$ and $\mathrm{K}$ improves the absorption of other nutrients and avoids morphological and physiological changes in crops, especially in those more sensitive to nutritional imbalance, such as melon. It should be pointed out that $\mathrm{K}$ is an important nutrient for $\mathrm{CO}_{2}$ assimilation, for the functioning of enzymes responsible for plant growth and, in addition, it substantially contributes to the absorption of $\mathrm{N}$, maximizing growth and yield (DEBBARMA et al., 2017; ZAHOOR et al., 2017).

Fertilizer use efficiency is a crucial parameter that relates crop yield to the applied 
quantity of a given nutrient. In this study, the $\mathrm{N}$ use efficiency (NUE) of melon plants was affected by the interaction between the factors $\mathrm{N}$ and $\mathrm{K}$. NUE increased as the $\mathrm{K}$ levels increased up to a certain point, but decreased considerably with the increase in $\mathrm{N}$ levels, and an estimated maximum of 368.15 $\mathrm{kg} \mathrm{kg}^{-1}$ was obtained using 45 and $183.75 \mathrm{~kg} \mathrm{ha}^{-1}$ of $\mathrm{N}$ and $\mathrm{K}$, respectively (Figure 5C).
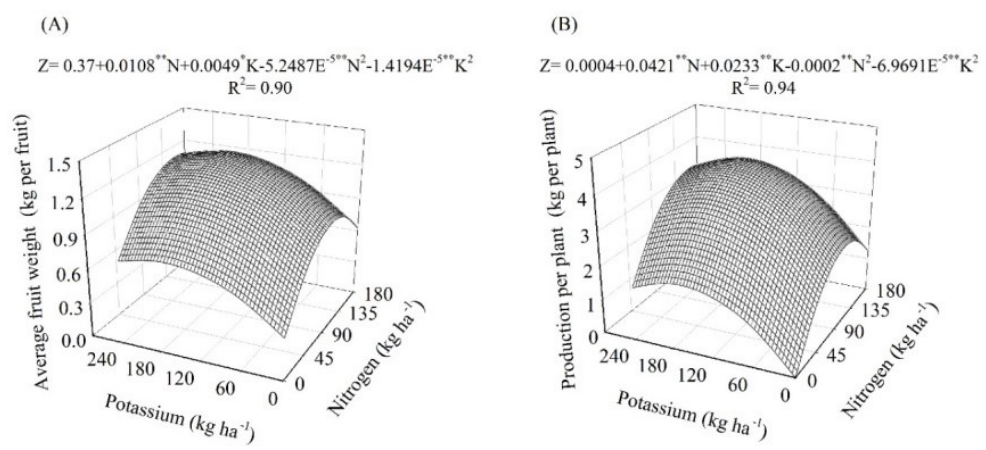

(C)

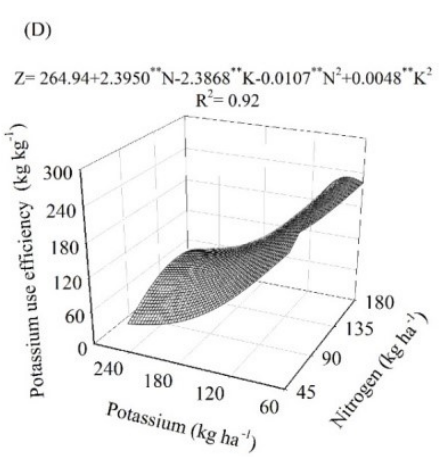

Figure 5. Response surfaces for average fruit weight (A), production per plant (B), nitrogen use efficiency (C) and potassium use efficiency (D) in melon as a function of nitrogen and potassium levels applied through fertigation.

** significant at $1 \%$ probability level, * significant at $5 \%$ probability level by Student's $t$ test.

The reduction in NUE with the increment in the $\mathrm{N}$ levels applied demonstrates that the increase in yield was proportionally lower than the quantity of $\mathrm{N}$ added, causing reduction in the efficiency of this production factor. Oliveira et al. (2008), Colla, Suárez and Cardarelli (2010), Castellanos et al. (2012) and Aouass, Kenny and Krim (2020) also observed reduction in the efficiency of $\mathrm{N}$ use by the melon crop with the increase in $\mathrm{N}$ availability. This behavior was also reported in another cucurbit species, watermelon, by Asad, Muien and Tariq (2019).

As observed for NUE, the potassium use efficiency (KUE) by melon was also significantly influenced by the interaction between treatments $(p<0.05)$. Significant effect of interaction between $\mathrm{N}$ and $\mathrm{K}$ applications on KUE by melon was also observed by Oliveira et al. (2008). Based on the slopes of the response surface (Figure 5D), it is possible to note that $\mathrm{N}$ maximized $\mathrm{KUE}$ up to a certain point, and this efficiency decreased as the applied levels of $\mathrm{K}$ increased. This demonstrates again that the increase of yield was also not proportional to the quantities of nutrients applied.

In the present study, maximum KUE of $272.57 \mathrm{~kg} \mathrm{~kg}^{-1}$ was found with $\mathrm{N}$ and $\mathrm{K}$ applications of 112.50 and $60 \mathrm{~kg} \mathrm{ha}^{-1}$, respectively (Figure 5D). This KUE value is lower than that observed by Oliveira et al. (2008), who obtained $305.57 \mathrm{~kg} \mathrm{~kg}^{-1}$ with the use of 42.00 and $106 \mathrm{~kg} \mathrm{ha}^{-1}$ of $\mathrm{N}$ and $\mathrm{K}$, respectively. These differences may be related to the efficiency of nutrient absorption by the roots of the cultivars and to the variations in local conditions of cultivation.

In sandy soils, with low cation exchange capacity (CEC), abundant presence of oxygen and not excessively acidic, as is the case of the Neossolo (Entisol) of this study, there is a predominance of nitrate $\left(\mathrm{NO}_{3}{ }^{-}\right)$in the soil solution and, under these conditions, $\mathrm{K}^{+}$adsorption is also reduced. Thus, applying high levels of $\mathrm{N}$ and $\mathrm{K}$ through irrigation water favors their leaching, resulting in a reduction in their use efficiencies (MENDES et al., 2016; SALIH et al., 2016; WANG et al., 2019). 
Efficiency of nitrogen...

\section{CONCLUSIONS}

Increase in the combined levels of nitrogen and potassium through fertigation positively influences the growth, physiological parameters and biomass production of 'Diplomata F1' yellow melon;
FERNANDES, P. C. A. et al.

Applications of $112.50 \mathrm{~kg} \mathrm{ha}^{-1}$ of $\mathrm{N}$ and 165 $\mathrm{kg} \mathrm{ha}^{-1}$ of K through fertigation promote the highest production per plant;

The combination between 45 and $183.75 \mathrm{~kg}$ $\mathrm{ha}^{-1}$ of $\mathrm{N}$ and $\mathrm{K}$, respectively, promotes maximum efficiency of $\mathrm{N}$ use, while the combination between 112.50 and $60 \mathrm{~kg} \mathrm{ha}^{-1}$ of $\mathrm{N}$ and $\mathrm{K}$, respectively, promotes maximum efficiency of $\mathrm{K}$ use by the melon.

RESUMO: As características fitotécnicas, de rendimento e de eficiência de uso dos fertilizantes são relevantes para o manejo racional da fertirrigação, especialmente em cultivo de elevado nível tecnológico. Níveis crescentes de $\mathrm{N}$ e $\mathrm{K}$ promoverão maior crescimento e produtividade do meloeiro. Neste sentido, objetivou-se avaliar a influência e a eficiência da aplicação de nitrogênio e potássio sobre as características fitotécnicas, de rendimento e de eficiência do meloeiro amarelo em sistema de fertirrigação. O experimento foi conduzido na cidade de Bom Jesus - PI, Brasil durante o período de janeiro a abril de 2016. O delineamento experimental adotado foi de blocos em faixas com quatro repetições, e os tratamentos constituídos por cinco níveis de nitrogênio $\left(0,45,90,135\right.$ e $180 \mathrm{~kg} \mathrm{ha}^{-1}$ na forma de ureia) e cinco níveis de potássio $(0,60,120,180 \mathrm{e}$ $240 \mathrm{~kg} \mathrm{ha}^{-1}$ na forma de cloreto de potássio) aplicados via fertirrigação. Avaliou-se os caracteres fitotécnicos, rendimento de frutos e as eficiências de uso do nitrogênio e do potássio. As aplicações de $180 \mathrm{~kg} \mathrm{ha}^{-1} \mathrm{de} \mathrm{N} \mathrm{e}$ $240 \mathrm{~kg} \mathrm{ha}^{-1}$ de $\mathrm{K}$ promoveram maior crescimento do meloeiro, enquanto que a máxima produção foi obtida com o uso de 112,50 e $165 \mathrm{~kg} \mathrm{ha}^{-1}$ de nitrogênio e potássio, respectivamente. As eficiências de uso do nitrogênio e do potássio diminuíram com o aumento dos níveis aplicadas.

PALAVRAS-CHAVE: Cucumis melo. Eficiência de uso de fertilizante. Fertirrigação.

\section{REFERENCES}

AOUASS, K.; KENNY, L.; KRIM, J. Nitrogen use efficiency in organic melon production under greenhouse conditions in South West of Morocco. Moroccan Journal of Agricultural Sciences, Morocco, v. 1, n. 2, p. 1$7,2020$.

ALI, S.; HAFEEZ, A.; MA, X.; TUNG, S. A.; CHATTHA, M. S.; SHAH, A. N.; LUO, D.; AHMAD, S.; LIU, J.; YANG, G. Equal potassium-nitrogen ratio regulated the nitrogen metabolism and yield of high-density lateplanted cotton (Gossypium hirsutum L.) in Yangtze River valley of China. Industrial Crops \& Products, Amsterdam, v. 129, p. 231-241, 2019. https://doi.org/10.1016/j.indcrop.2018.12.009

ALLEN, R. G.; PEREIRA, L. S.; RAES, D.; SMITH, M. Evapotranspiración del cultivo: guia para la determinacion de los requerimientos de agua de los cultivos. Roma: FAO, 2006, 298p. Available from: http://www.fao.org/3/x0490s/x0490s.pdf

ANDRADE JUNIOR, A. S.; DIAS, N. S.; FIGUEREDO JUNIOR, L. G. M. Frequência de aplicação de nitrogênio e de potássio via água de irrigação por gotejamento na cultura da Melancia em Parnaíba, PI.

Agropecuária Científica no Semi-Árido, Campina Grande, v. 3, p. 1-7, 2007.

AQUINO, A. B.; AQUINO, B. F.; HERNANDEZ, F. F. F.; HOLANDA, F.J.M.; FREIRE, J.M.; CRISÓSTOMO, L. A.; COSTA, R. I.; UCHÔA, S. C.P.; FERNANDES, V. L. B.; AQUINO, A.; AQUINO, L. F.; HERNÁNDEZ, F. G.B.; HOLANDA, F. J. M.; FREIRE, G.; CRISÓSTOMO, L. D.; COSTA, R. C.; UCHÔA, S.; FERNANDES, R.; FERNANDES, V.; AQUINO, C. A. B. A.; AQUINO, A.; CASTRO, F. H.; HOLANDA, F.; FREIRE, F.; CRISÓSTOMO, E.; COSTA, J.; UCHÔA, P.; FERENADES, B.

Recomendações de adubação e calagem para o Estado do Ceará. Fortaleza: Editora da UFC, 1993, 248p. 
ASAD, M. F. A.; MUIEN M. Q.; TARIQ, Y. M. O. Effect of nitrogen on yield, quality, and irrigation water use efficiency of drip fertigated grafted watermelon (Citrullus lanatus) grown on a calcareous soil. Journal of Plant Nutrition, Abingdon, v. 42, n. 7, p. 737-748, 2019. https://doi.org/10.1080/01904167.2019.1568464

CASTEllanos, M. T.; CABELlO, M. J.; CARTAGENA, M. C.; TARQUIS, A. M.; ARCE, A.; RIBAS, F. Nitrogen uptake dynamics, yield and quality as influenced by nitrogen fertilization in 'Piel de sapo' melon. Spanish Journal of Agricultural Research, Madri, v. 10, n. 3, p. 756-767, 2012. https://doi.org/10.5424/sjar/2012103-437-11

COLLA, G.; SUÁREZ, C. M. C.; CARDARELLI, M. Improving nitrogen use efficiency in melon by grafting. HortScience, Alexandria, v. 45, n. 4, p. 559-565, 2010. https://doi.org/10.21273/HORTSCI.45.4.559

DEBBARMA, J.; ALILA, P.; BANIK, M.; MANDAL, A. K.; CHAKMA, A. Effect of different levels of nitrogen and potassium on the growth and yield of Pepino (Solanum muricatum Ait.). The Pharma Innovation Journal Research, New Delhi, v. 6, n. 11, p. 817-821, 2017.

EMBRAPA - Empresa Brasileira de Pesquisa Agropecuária. Manual de Métodos de Análise de Solo. 3rd ed. Brasília, DF: Embrapa, 2017.

EMBRAPA - Empresa Brasileira de Pesquisa Agropecuária. Sistema brasileiro de classificação de solos. 5th ed. Brasília, DF: Embrapa, 2018.

HAGEL, H.; HOFFMANN, C.; IRMÃO, J. F.; DOLUSCHITZ, R. Socio-economic aspects of irrigation agriculture as livelihood for rural families in Brazil's semi-arid northeast. Journal of Agriculture and Rural Development in the Tropics and Subtropics, Witzenhausen, v. 120, n. 2, p. 157-169, 2019. https://doi.org/10.17170/kobra-20191127814

HOLANDA, J. S.; AMORIM, J. R. A.; FERREIRA NETO, M.; HOLANDA, A. C.; SÁ, F. V. S. Qualidade da água para irrigação. In: GHEYI, H. R.; DIAS, N. S.; LACERDA, C. F., GOMES FILHO, E. (Eds.). Manejo da salinidade e na agricultura: estudos básicos e aplicados. Fortaleza: INCTSal, 2016.

IBGE. Instituto Brasileiro de Geografia e Estatística. Sistema IBGE de Recuperação Automática - SIDRA: banco de dados agregados. Produção Agrícola Nacional: Lavouras Temporárias [online]. IBGE, 2020. Available from: https://sidra.ibge.gov.br/tabela/1612\#resultado

MEDEIROS, R. M.; SILVA, V. M. A.; MELO, V. S.; MENEZES, H. E. A.; MENEZES, H. E. A. Diagnóstico e tendência da precipitação pluvial em Bom Jesus - Piauí, Brasil. Revista Verde de Agroecologia e

Desenvolvimento Sustentável, Pombal, v. 11, n. 3, p. 115-121, 2016.

https://doi.org/10.18378/rvads.v11i3.3992

MENDES, W. C.; ALVES JÚNIOR, J.; CUNHA, P. C. R.; SILVA, A. R.; EVANGELISTA, A. W. P.; CASAROLI, D. Potassium leaching in different soils as a function of irrigation depths. Revista Brasileira de Engenharia Agrícola e Ambiental, Campina Grande, v. 20, n. 11, p. 972-977, 2016.

https://doi.org/10.1590/1807-1929/agriambi.v20n11p972-977

NASCIMENTO, C., NASCIMENTO, C.; CECÍLIO FILHO, A. B. N: K ratio for phenological growth stages of net melon Cultivated in NFT hydroponic system. Revista Caatinga, Mossoró, v. 33, n. 1, p. 108-115, 2020. http://dx.doi.org/10.1590/1983-21252020v33n112rc

OLIVEIRA, F. A.; MEDEIROS, J. F.; LIMA, C. J. G. S.; DUTRA, I.; OLIVEIRA, M. K. T. Eficiência agronômica da fertirrigação nitrogenada e potássica na cultura do meloeiro nas condições do semi-árido nordestino. Revista Caatinga, Mossoró, v. 21, n. 5, p. 5-11, 2008. 
PEREIRA FILHO, J. V.; BEZERRA, F. M. L.; SILVA, A. R. A.; SOUSA, C. C. M. S.; CASTRO, J. M. Frequência de irrigação e aplicação de $\mathrm{N}$ em meloeiro irrigado por gotejamento nas condições semiáridas do Nordeste, Científica, Jaboticabal, v. 42, n. 1, p. 11-22, 2014. https://doi.org/10.15361/1984-5529.2014v42n1p11-22

PERCHLIK, M.; TEGEDER, M. Leaf amino acid supply affects photosynthetic and plant nitrogen use efficiency under nitrogen stress. Plant Physiology, Oxford, v. 178, n. 1, p. 174-188, 2018. https://doi.org/10.1104/pp.18.00597

PRADO, R. M. Nutrição de plantas. São Paulo: editora Unesp. 2008, 407p.

SALIH, R. F.; ABDAN, K.; WAYAYOK, A.; HASHIM, N.; RAHMAN, K. A. Improve quality and quantity of plant products by applying potassium nutrient (A Critical Review). Journal of Zankoy Sulaimani, Sulaimani, v.18, n. 1, p. 197-207, 2016. https://doi.org/10.17656/jzs.10514

SANTOS, G. R.; BONIFACIO, A.; RODRIGUES, A. C.; DALCIN, M. S.; SARMENTO, R. A.; NASCIMENTO, I. R. Melon fruit quality front mildew incidence and management of nitrogen and potassium topdressing. Comunicata Scientiae, Bom Jesus, v. 9, n. 3, p. 372-380, 2018.

https://doi.org/10.14295/CS.v9i3.1566

SILVA, M. C.; SILVA, T. J. A.; BONFIM-SILVA, E. M.; FARIAS, L. N. Características produtivas e qualitativas de melão rendilhado adubado com nitrogênio e potássio. Revista Brasileira de Engenharia Agrícola e Ambiental, Campina Grande, v. 18, n. 6, p. 581-587, 2014.

https://doi.org/10.1590/S1415-43662014000600003

WANG, P.; WANG, Z.; SUN, X.; MU, X.; CHEN, H.; CHEN, F.; YUAN, L.; MI, G. Interaction effect of nitrogen form and planting density on plant growth and nutrient uptake in maize seedlings. Journal of Integrative Agriculture, Beijing, v. 18, n. 5, p. 1120-1129, 2019. https://doi.org/10.1016/S2095-3119(18)61977-X

ZAHOOR, R.; DONG, H.; ABID, M.; ZHAO, W.; WANG, Y.; ZHOU, Z. Potassium fertilizer improves drought stress alleviation potential in cotton by enhancing photosynthesis and carbohydrate metabolism. Environmental and Experimental Botany, Amsterdam, v. 137, n. 1, p. 73-83, 2017. https://doi.org/doi:10.1016/j.envexpbot.2017.02.002

ZÖRB, C., SENBAYRAM, M.; PEITER, E. Potassium in agriculture: status and perspectives. Journal of Plant Physiology, Stuttgart, v. 171, n. 9, p. 656-669, 2014. https://doi.org/10.1016/j.jplph.2013.08.008 